\title{
Interactive WhiteBoard: Effective Interactive Teaching Strategy Designs for Biology Teaching
}

\author{
Kai-Ti Yang ${ }^{1}$ and Tzu-Hua Wang2,* \\ ${ }^{1}$ National Taiwan Normal University \\ ${ }^{2}$ National HsinChu University of Education \\ Taiwan (R.O.C.)
}

\section{Introduction}

The goal of this chapter is to design interactive teaching strategies with Interactive WhiteBoard (IWB) and investigate their effectiveness on Biology teaching. In recent years, with the rapid development of Information Communication Technology (ICT), integrating multimedia presentation tools to perform better teaching has become easier in today's classroom. Among many ICT systems, the innovation and introduction of IWB has not only changed the traditional classroom but symbolizes a key revolution in the history of whiteboard development. Researchers have identified a number of advantages of using IWB in teaching and learning: flexibility and versatility, multimedia/multimodal presentation, improving teaching efficiency, supporting planning and the development of resources, improving students' skills of using ICT technology, interactivity and participation during course, improving students' learning motivation, and improving students' understanding (BECTA, 2007; Glover, Miller, Averis, \& Door, 2005; Holmes, 2009; Northcote, Mildenhall, Marshall, \& Swan,2010;Slay, Sieborger, \& Hadgkinson-Williams, 2008; Smith, Higgins, Wall, \& Miller, 2005; Wall, Higgins, Smith, 2005). The IWB realizes interactive operations between the whiteboard and the computer. It has become a new interface to consolidate all teaching resources in a traditional classroom. Many countries, such as the United Kingdom, Japan, Singapore, Malaysia, China, and Russia, have invested heavily in the IWB and attempted to implement it in schools of all levels. In Taiwan, the government also invests a large amount of money to introduce IWB into classrooms. Since 2006, the Taiwan's Ministry of Education officially announced that more than $\$ 50$ million NTD (roughly $\$ 15$ million USD) would be invested in promoting the preliminary integration of IWB into instruction. Following the trend of integrating IWB into teaching, this research tries to understand how to make good use of the advantages of IWB to make students have better learning effectiveness on junior high school Biology.

Among the topics of junior high school Biology, cell division, photosynthesis, cell respiration, food chain, food web and evolution are the topics difficult to teach and learn. Both teachers

${ }^{*}$ Corresponding Author 
and students believe that cell division is most difficult to learn of all topics (Oztap, Ozay, \& Oztap, 2003). Many related studies have shown that students of different ages and in different grades all have a poor understanding of cell division (Lewis, Leach, Wood-Roinson, 2000a, b; Lewis \& Wood-Roinson, 2000; Smith, 1991). Lewis et al. (2000a, b) pointed out that students had a poor understanding of cell division because they are not clear about the basic structures of genetics and therefore easily become confused about the terminology. Lewis et al. argued that students will be able to develop a better understanding if these basic structures are clearly presented. Brown (1995) and Oztap et al. (2003) noted that teaching needs to emphasize the dynamic nature of the cell division using a variety of teaching aids such as photographs, film and videos, particularly time-lapse phase contrast microscopy, to demonstrate the change of the chromosomes at different stages of cell division and build chromosome models so that it will be easier for students to overcome learning difficulties.

The major advantages of IWB indicated in the literature and their potential in Biology teaching are explained as follows (BECTA, 2007; Glover et al., 2005; Holmes, 2009; Northcote et al., 2010; Slay et al., 2008; Smith et al., 2005; Wall et al., 2005) :

\section{Advantage 1: Flexibility and versatility}

The IWB can be used in teaching students of different ages and for different topics. Its functions, including making notes, flipping back and forth to review material, saving the drawings and texts, and moving the intended objects and focusing on them. It can improve flexibility and versatility of teaching. Therefore, IWB is suitable for teaching high school Biology courses. In addition, IWB can focus on specified content and enlarge multimedia objects based on teacher and student needs. Notes can also be made on the content through the IWB screen. Moreover, teachers can record the teaching process (including the notes) and interactions with students for later review.

\section{Advantage 2: Multimedia/Multimodal presentation}

The IWB is a new interface integrating all teaching resources. Its built-in teaching software and dynamic multimedia presentation can attract students' attention and help them understand abstract concepts. In Biology teaching, the visual nature of IWB presentations can improve student learning by delivering micro or dynamic representations of abstract concepts such as the process of cell division or the structures and functions inside bodies such as blood circulation. IWB also supports multimedia and multimodal presentation. Multiple representations can be simultaneously shown on the screen to satisfy needs of students with different learning styles.

\section{Advantage 3: Improving teaching efficiency}

Teachers can present many multimedia resources on the IWB to improve teaching efficiency. For example, the structures of chromosomes can be presented using images, videos or 3D models to help students build chromosome models. In addition, students can use the IWB to improve and facilitate their learning process. Teachers can design teaching activities for the IWB, which may help students actively think and operate the IWB. For example, teachers can provide unfinished flow charts about the process of cell division for students to complete through discussion. Teachers can also provide students pictures about chromosomes' changes in each stage of cell division and make them arrange the pictures in right order and explain how the quantity of DNA and chromosome changes. 


\section{Advantage 4: Supporting planning and the development of resources}

The IWB has a large teaching material resource database where teachers can access various animations and music for different subjects, such as frog anatomy, and use them to develop digital materials for teaching activities.

\section{Advantage 5: Improving students' skills of using ICT technology}

Teachers can use the IWB to help students better engage in the learning environment. Students can improve their skills in using ICT by discussing with peers or observing teachers' and peers' operation.

\section{Advantage 6: Interactivity and participation during course}

The interactivity enabled by IWB can improve interaction in classroom and make students and teachers feel closer to each other. They can have more eye-contact than using laptops and teachers are therefore more able to control the classroom. Moreover, the IWB is more beneficial to the teaching of subjects involving many inquiry activities and requiring extensive participation of students, such as science subjects.

\section{Advantage 7: Improving students' learning motivation}

The IWB's ability to dynamically integrate audio and visual presentation can make teaching activities more lively and realistic. Compared with common 2D presentations and textbooks, IWB can better attract students' attention and enhance their learning motivation.

\section{Advantage 8: Improving students' understanding}

The IWB is characterized by visual nature and supports multiple representations, which not only attracts students' attention but improves their understanding of the topics. For example, an IWB can simultaneously show on its large screen the 2D pictures of chromosome structures and a 3D video demonstrating the relation between chromosomes, genes and genetic information. This can not only improve understanding of students with different learning styles but enhance their ability to interpret the relationship between the 2D pictures and the 3D video by combining the information they deliver.

The abovementioned advantages of integrating IWB into the teaching of junior high school Biology courses show that introducing IWB into the classroom will be able to provide teachers with a way to present the dynamic nature of cell division, and the relationships between cells, chromosomes, genes and genetic information with multimedia and multimodal representation. Students can in turn develop a thorough concept structure. Moreover, IWB's high interactivity facilitates student participation in learning and promotes their learning motivation. With this in mind, in this research we design digital teaching materials and activities that use the IWB to teach cell division, in order to investigate the viability and effectiveness of integrating IWB into the teaching of cell division. This research adopts a quasiexperimental design to investigate the effectiveness of IWB-integrated instruction and traditional ICT-integrated instruction on junior high school Biology teaching.

\section{Methodology}

This section introduces the participants, instruments, research design, and data collection and analysis of this research. 


\subsection{Participants}

Fifty-four junior high school seventh graders participated in this study. Adopting a quasiexperimental design, this study divided the participating students into two groups, the IWB group $(n=27)$ and the $T$ group $(n=27)$. The $T$ group received traditional ICT-integrated instruction, which means the teacher lectured by projecting Microsoft PowerPoint slides onto the projection screen. The IWB group received IWB-integrated instruction.

\subsection{Instruments}

\subsubsection{Interactive Whiteboard (IWB) - SmartBoard ${ }^{\mathrm{TM}}$}

The IWB used in this study is the SmartBoardTM made by a Canadian company, SMARTTM Technologies, using analog resistive technology. The whiteboard is connected to a notebook or a computer through the USB cable, and then the notebook or computer is connected to the projector. Signals of the projector are projected onto the IWB. By adjusting the IWB, teachers can operate the computer by touching the IWB, as shown in Figure 1. The IWB can immediately save the written texts, drawings and other messages on the IWB panel to the connected computer.

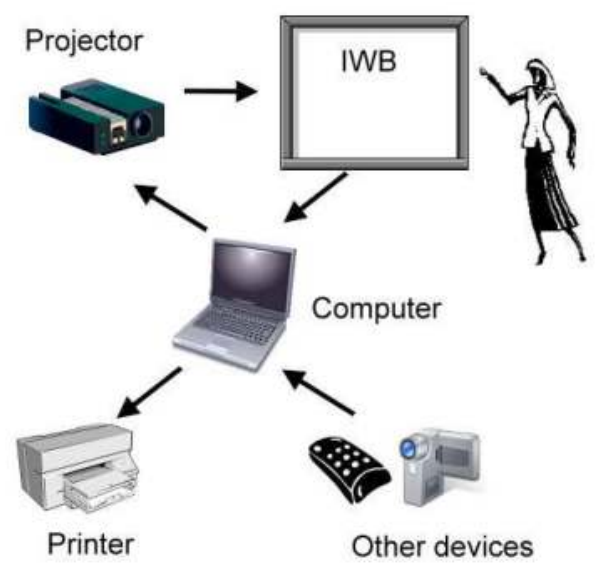

Fig. 1. Interactive Whiteboard system structure and operation

\subsubsection{Digital teaching materials and teaching method}

Teaching materials used in this study focus on the 'Cell Division' topic of junior high school Biology course in Taiwan. Teaching contents cover three sub-topics: 'Chromosome and Its Importance,' 'The Role of Mitosis' and 'Meiosis and Sexual Life Cycle.' Teaching materials for 'Chromosome and Its Importance' focus on the following concepts: chromosomes are located in nucleus; chromosomes contain heredity substances - genes to determine individual's traits; chromosome number varies with species; homologous chromosomes. 'The Role of Mitosis' and 'Meiosis and Sexual Life Cycle' primarily aim to enable students to understand when mitosis and meiosis happen and the significance of the two kinds of cell division. 
The digital teaching materials designed in this study are mainly images, pictures and Adobe Flash animations. Materials used by the two groups included the same concepts, and both groups were lectured by the same teacher. The main difference is that in the IWB group, the digital teaching materials can be used on the NoteBook ${ }^{\mathrm{TM}}$ software, which is provided by SMARTTM Technologies. Further, the teacher can interact with the students through the IWB screen. In the $\mathrm{T}$ group, the digital teaching materials are presented for teaching in the traditional way of using a projector to project PowerPoint slides onto the screen, and interaction between the teacher and students is limited to verbal communication. The teaching methods of the IWB and the T group are explained below.

\subsubsection{Teaching method of IWB group}

Prior to teaching, students have prior knowledge about cells. They know that the nucleus is related to heredity but are not clear about its contents. Lewis et al. (2000a, b) pointed out that junior high school students are not clear about the relationship between the cell, chromosomes and genetic information. If students would like to develop a coherent conceptual framework for a better understanding of genetics and inheritance, they first must have a clear understanding if the relationship between the basic structures - cell, nucleus, chromosome and gene. Therefore, in 'Chromosome and Its Importance,' the teacher enables the students understand the relationship between the cell, the nucleus, chromatins, chromosomes, genes and genetic information through the images from microscopes and 2D pictures. Moreover, to enhance student understanding of the relationship between the cell, the nucleus, chromosomes and genes, the teacher designs activities that call for the students to answer questions and touch the IWB to collaboratively match the genetic structures. This section also includes the interpretation and application of DNA fingerprint. The teacher also designs an activity to make students work together to identify the blood relationship between a child and his parents through the knowledge about DNA fingerprint and explain the reasons for peers (Figure 2). Moreover, to resolve student misconceptions about sex

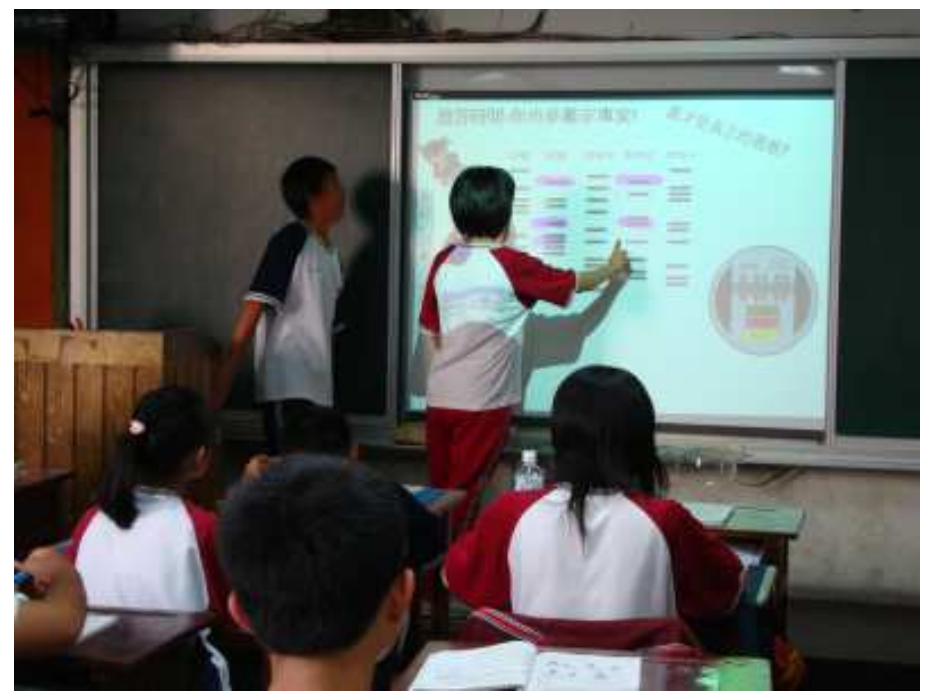

Fig. 2. Students are learning in IWB group 
chromosomes (X , Y chromosome) and autosomes identified by Lewis et al.(2000a), students are made to directly compare the karyotypes of male and female, circle the differences on the IWB themselves, and count the number of chromosomes. In addition, students are allowed to touch the species on the Adobe Flash animation whose chromosome number they would like to know. After comparison, they can come out with the conclusion that different species have different chromosome numbers and that the chromosome number does not imply a hierarchy of species (Figure 3). Finally, the concepts about homologous chromosomes, ploidy and alleles are introduced through human karyotypes. By dragging and making the separated homologous chromosomes together through the IWB, students will acquire a better understanding of the concept. In order to enable students to clearly identify concepts about alleles, this information is presented using cartoon pictures - In addition, the concept of ploidy is presented by having students compare the karyotypes of human somatic cells and germ cells.

In 'The Role of Mitosis,' the $\mathrm{Q}$ and $\mathrm{A}$ teaching activities are used to help students understand the significance and process of mitosis. The IWB screen is divided into two parts. The left part presents the significance of mitosis, the process by which a cell is divided into two identical cells. On the right, the IWB displays the process of mitosis but does not show how the chromosomes change in the nucleus (see step1 in Figure 4). Instead, to enable students to think actively about the chromosome change in mitosis, the teacher adopts $Q$ and A teaching activities that compel the students to answer the questions about chromosome changes in each stage (see step2 and step3 in Figures 4). Moreover, to clear students' confusion about the terminology, students are made to match the terminology, including 'chromosome duplication,' 'chromosomes convene on the metaphase plate,'
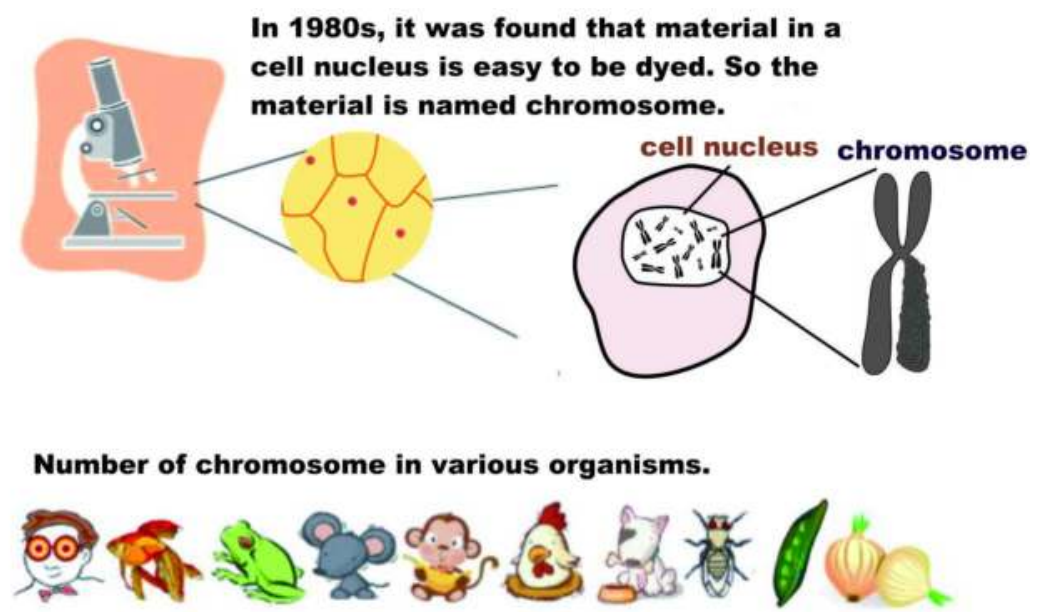

14

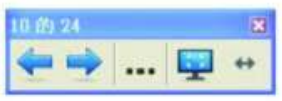

Fig. 3. Screenshot of the teaching materials (Yang, Wang, \& Chiu, 2011) 
'separation of sister chromatids' and 'one cell divides into two identical cells,' with their corresponding stages (see step4 in Figures 4). Then, to make students have a deeper impression and understanding of the changes in ploidy, DNA quantity and chromosome number, pictures of each stage of mitosis are projected on the IWB screen for students to work together in assigning them to the mitosis process on the correct stages(see 1-5 in Figure 5), explaining the reason for their operation, assigning the descriptions(see part A in Figure 5) on the correct arrows (see part B in Figure 5), and then drawing diagrams about the changes in ploidy, DNA quantity and chromosome number (see part C in Figure 5).

In 'Meiosis and Sexual Life Cycle,' the teacher also adopts $Q$ and A teaching activities to enable the students to understand the significance of meiosis and when and where it happens. Human karyotypes are also used to help students understand that if meiosis does not occur in gametes before fertilization, the problem of tetraploidy may happen. Then students learn about meiosis using similar methods stated above. They are first guided to answer the chromosome change of meiosis stage by stage and then compare the differences between meiosis and mitosis. Students need to identity the following concepts about meiosis: 'chromosomes replicate once but divide twice,' 'there are four daughter cells,' 'homologs separate during anaphase I' and 'sister chromatids separate during anaphase II.' They make notes on the IWB screen and understand the concept that meiosis is the main cause of genetic variation in the sexual life cycle. Moreover, by competing to answer questions

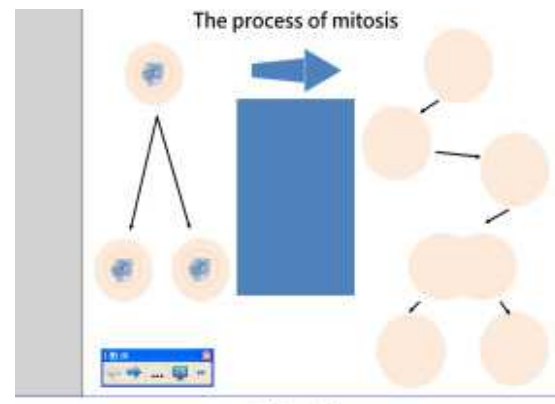

step1

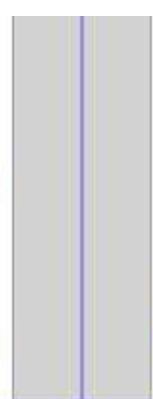

(1)

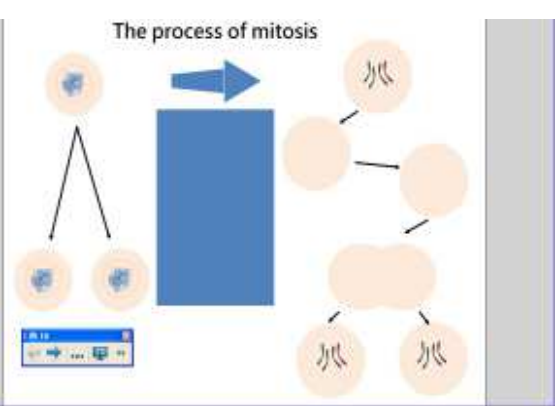

step2

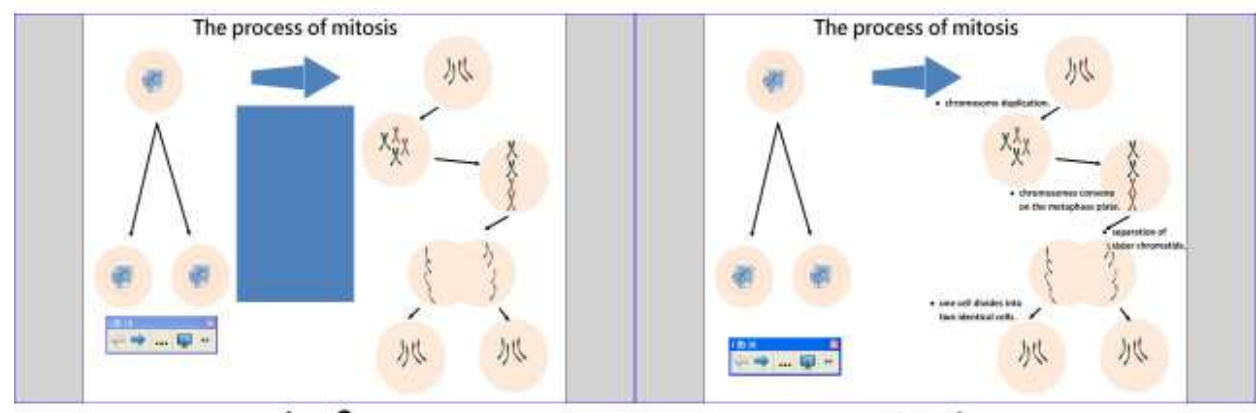

step3

step4

Fig. 4. The four steps of teaching the concept of mitosis in IWB group. The big rectangles in this figure are the masks for the correct answers. 


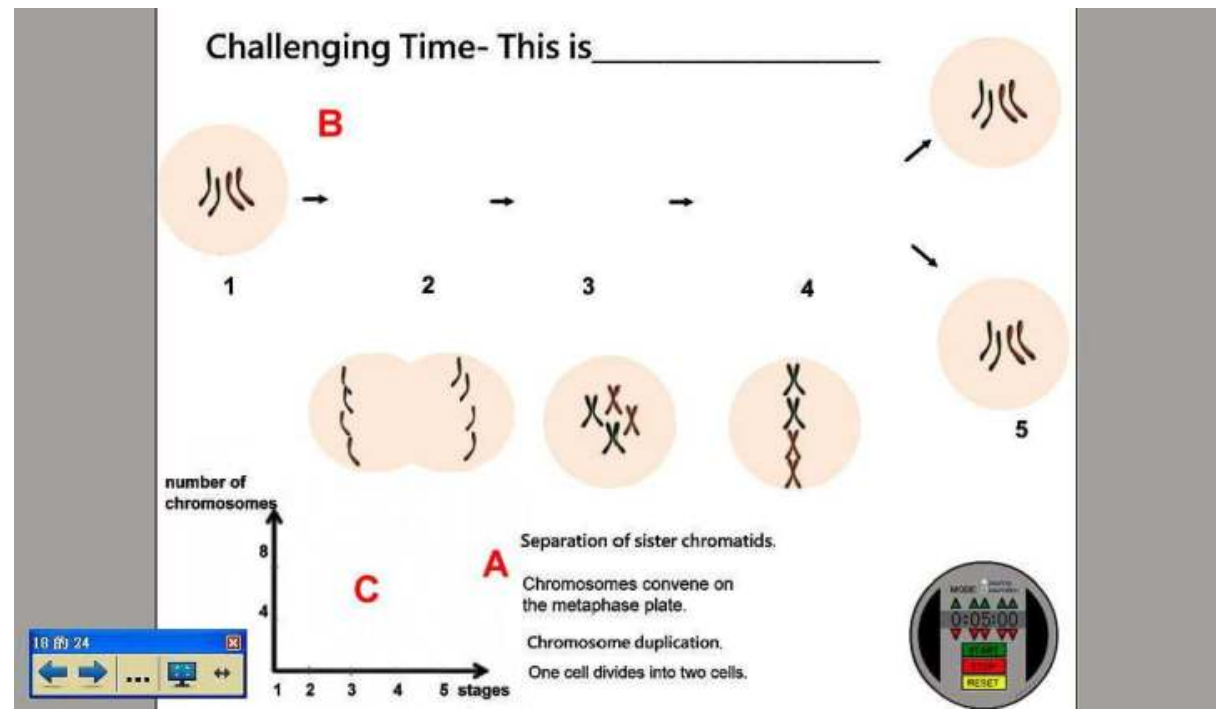

Fig. 5. Screenshot of the teaching materials for the concept of mitosis in IWB group

and working together to complete the meiosis process, using similar methods stated above, students can familiarize themselves with the process of meiosis again. They are also required to draw the changes in the number of chromosome sets, chromosome numbers and the DNA quantity.

Finally, to enable students to clearly distinguish mitosis from meiosis, the teacher makes two tables comparing the two kinds of cell division, sexual reproduction and asexual reproduction on IWB screen, and then has the students complete the tables collaboratively. Their commonalities and differences are presented explicitly, as suggested by Lewis et al. (2000a).

\subsubsection{Teaching method of T group}

The digital teaching materials used by the IWB group and the T group cover the same concepts and are presented by the same teacher. The main difference is that in the IWB group, the digital teaching materials can be used for teaching on the IWB, while in the T group, these digital teaching materials are presented in the traditional way of using a projector to project MicroSoft PowerPoint slides (PPT slides) onto the screen, and interaction between the teacher and students is limited to verbal communication. In other words, the IWB and $T$ groups present the same teaching materials in the same order. The only difference is that in the IWB group, students are allowed to operate the IWB collaboratively during teaching activities. In the $T$ group, students only answer questions verbally during $Q$ \& A teaching activities, and the teacher presents teaching materials with PPT slides one by one. Therefore, in the sub-topic of 'Chromosome and Its Importance,' teaching materials are all designed to enable students in the T group to learn the basic structures through pictures. However, in the IWB group, students compete to answer questions and do the matching about relationship between basic structures on the IWB. In the T group, after the teacher raises questions, students compete to answer and then the teacher uses simple animations 
embedded in the PPT slides to present the relationship between basic structures. In addition, there is also a $\mathrm{Q} \& \mathrm{~A}$ teaching activity after the teacher explains how to interpret and apply DNA fingerprint. After students compete to answer questions, the teacher shows the correct answers with the animations embedded in the PPT slides. Moreover, the teacher directly demonstrates the Adobe Flash animation illustrating that the location and contents of chromosomes and the chromosome number varies with species.

In the sub-topic of 'The Role of Mitosis,' the Q \& A teaching activities are used to help students understand the significance of mitosis. The screen of the PPT slide is divided into two parts. The left side of the screen shows the significance of cell division - a single cell is divided into two identical cells. The right side of the screen shows the diagram the process of mitosis but not the changes of chromosomes in the nucleus. After conducting $\mathrm{Q} \& \mathrm{~A}$ teaching activities with students, the teacher displays the animation embedded in the PPT slides to show how the chromosomes change in each stage and the terminology of each stage during the mitosis process (Figure 6). To give the students a deeper understanding of the changes in the number of chromosome sets, chromosome number, and quantity of DNA, the teacher also presents the PPT slides and displays the animation embedded in the PPT slides to present the process of mitosis and changes of DNA and chromosomes after having Q \& A teaching activities with students. The teacher teaches the sub-topic of 'Meiosis and Sexual Life Cycle' in the same way as the sub-topic of 'The Role of Mitosis.' The table is also shown in the animations built into the PPT slides after the teacher finish the Q \& A teaching activity interaction with her students.

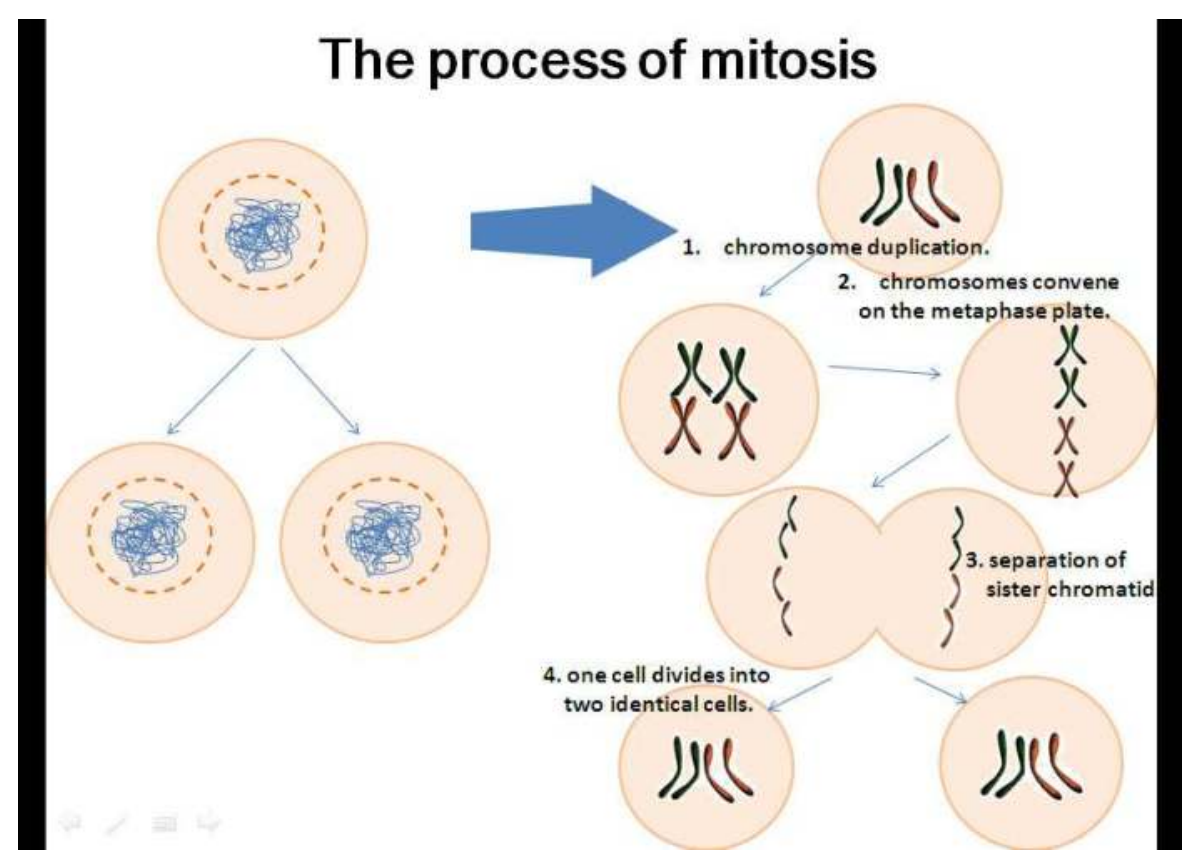

Fig. 6. Screenshot of the teaching materials for the concept of mitosis in T group 


\subsubsection{Comparison of IWB and Traditional technology-integrated teaching method}

Differences between the teaching methods of the IWB and the T group are listed in the Table 1:

\begin{tabular}{|c|c|c|}
\hline Teaching sub-topics & IWB group & T group \\
\hline $\begin{array}{l}\text { Chromosome and Its } \\
\text { Importance }\end{array}$ & $\begin{array}{l}\text { - In addition to using } \\
\text { pictures to present the } \\
\text { basic structures, } \\
\text { students also match } \\
\text { pictures of the basic } \\
\text { genetic structures by } \\
\text { competing to answer } \\
\text { questions, touching the } \\
\text { IWB or coloring and } \\
\text { circling with colored } \\
\text { pens so that their } \\
\text { understanding and } \\
\text { impression of the } \\
\text { concepts and } \\
\text { terminology can be } \\
\text { enhanced. } \\
\text { Karyotypes of male } \\
\text { and female are } \\
\text { simultaneously shown } \\
\text { on the large screen of } \\
\text { the IWB, which is used } \\
\text { to help students } \\
\text { understand the } \\
\text { concepts of sex } \\
\text { chromosomes and } \\
\text { autosomes. } \\
\text { Students can actively } \\
\text { play the Adobe Flash } \\
\text { animations so that their } \\
\text { understanding and } \\
\text { impression of the } \\
\text { concepts and their ICT } \\
\text { skills can be improved. }\end{array}$ & $\begin{array}{l}\text { - } \text { Although PPT slides } \\
\text { can present many } \\
\text { pictures and } \\
\text { animations, the } \\
\text { animations embedded } \\
\text { in the PPT slides are } \\
\text { displayed linearly after } \\
\text { Q \& A teaching } \\
\text { activities. } \\
\text { Teacher's interaction } \\
\text { with students is limited } \\
\text { to verbal } \\
\text { communication; all } \\
\text { software operation is } \\
\text { done by the teacher. }\end{array}$ \\
\hline The Role of Mitosis & $\begin{array}{l}\text { The large screen of the } \\
\text { IWB is divided into } \\
\text { two parts so that } \\
\text { information can be } \\
\text { more easily shown } \\
\text { together to guide } \\
\text { students to think about } \\
\text { and complete each } \\
\text { stage of mitosis and }\end{array}$ & $\begin{array}{l}\text { - Animations embedded } \\
\text { in the PPT slides are } \\
\text { displayed linearly after } \\
\text { Q \& A teaching } \\
\text { activities. } \\
\text { Teacher's interaction } \\
\text { with students is limited } \\
\text { to verbal } \\
\text { communication; all } \\
\end{array}$ \\
\hline
\end{tabular}




\begin{tabular}{|c|c|c|c|}
\hline & & $\begin{array}{l}\text { enable them to clearly } \\
\text { learn the related } \\
\text { terminology. } \\
\text { To improve students' } \\
\text { understanding, } \\
\text { activities are designed } \\
\text { to make students } \\
\text { compete to answer } \\
\text { questions, work } \\
\text { together operating the } \\
\text { IWB to complete the } \\
\text { process of mitosis and } \\
\text { draw the changes in the } \\
\text { chromosome number, } \\
\text { quantity of DNA and } \\
\text { chromosome sets. }\end{array}$ & $\begin{array}{l}\text { software operation is } \\
\text { done by the teacher. }\end{array}$ \\
\hline $\begin{array}{l}\text { Meiosis and Sexual Life } \\
\text { Cycle }\end{array}$ & • & $\begin{array}{l}\text { The teaching method is } \\
\text { the same as that used to } \\
\text { teach mitosis, but the } \\
\text { IWB can provide rapid } \\
\text { cross-page comparison } \\
\text { and it is convenient to } \\
\text { make notes on the IWB } \\
\text { screen to enable the } \\
\text { students to clearly } \\
\text { understand the } \\
\text { difference between the } \\
\text { two kinds of cell } \\
\text { division. } \\
\text { Students are allowed to } \\
\text { write on the IWB and } \\
\text { compare mitosis with } \\
\text { meiosis and sexual } \\
\text { reproduction with } \\
\text { asexual reproduction } \\
\text { so that their } \\
\text { understanding of the } \\
\text { relationship can be } \\
\text { improved. }\end{array}$ & $\begin{array}{l}\text { - Animations embedded } \\
\text { in the PPT slides are } \\
\text { displayed linearly after } \\
\text { Q \& A teaching } \\
\text { activities. } \\
\text { Teacher's interaction } \\
\text { with students is limited } \\
\text { to verbal } \\
\text { communication; all } \\
\text { software operation is } \\
\text { done by the teacher. }\end{array}$ \\
\hline
\end{tabular}

Table 1. Comparison of the teaching activities in IWB and T groups

\subsubsection{Summative assessment}

The summative assessment in this research is used to understand student learning effectiveness. The design of the 25 summative assessment items are based on the teaching materials and a Two-Way Chart is used to ensure a reasonable distribution of the items. The summative assessment was also reviewed by two experts in assessment and course design 
and one experienced junior high school Biology teacher. The Cronbach a of the summative assessment is 0.860 . The average difficulty is 0.564 .

\subsection{Research design}

To understand how the integration of the IWB into teaching influences the learning effectiveness of seventh graders in a junior high school in Taiwan, this research uses the quasi-experimental design to divide the participants into the experimental group (IWB group) and the control group ( $\mathrm{T}$ group). IWB group learns in the teaching environment integrated with IWB while the T group learns in an environment using traditional ICT, The where teaching is done by projecting Microsoft PowerPoint slides onto a traditional projection screen through a projector. However, the two groups are lectured by the same teacher. Before teaching, to understand the student's entry behavior of learning, students were asked to take the pre-test of the summative assessment. Then students received five classes in which the information technology was integrated into the instruction. After the five classes, students took the post-test of the summative assessment.

\subsection{Data collection and analysis}

The data collected are all quantitative data, including the pre-test and post-test scores of the summative assessment. To investigate how integrating an IWB into teaching of junior high school cell division influences student learning effectiveness, this study uses two different kinds of data analysis techniques. First, to investigate the effectiveness of two different types of teaching method, ANCOVA was conducted on the scores of the summative assessment. The pre-test scores of the summative assessment are taken as covariate, the two different types of teaching method as a fixed factor and the post-test scores of the summative assessment as the dependent variable. This analysis aims to understand how the two different types of teaching method influence the learning effectiveness of junior high school students. This study further adopts effect size analysis (Cohen, 1988) to investigate how the two different types of teaching methods influence student learning effectiveness on the three different sub-topics. According to the definition of Cohen (1988), Cohen's $d$ less than 0.2 means 'small' effect size, between 0.2 and 0.5 means 'small to middle' effect size, between 0.5 and 0.8 means 'middle to large' effect size, while larger than 0.8 means 'large' effect size.

\section{Results}

To investigate the effectiveness of IWB-integrated instruction and traditional ICT-integrated instruction on junior high school Biology teaching, this research adopts ANCOVA and effect size analysis to perform data analysis.

\subsection{Effectiveness of two different types of teaching method}

To understand the influences on junior high school student learning effectiveness of the two different types of teaching method (TTM), this study compares the student learning effectiveness of the IWB group and the T group using ANCOVA. The TTM is taken as the fixed factor, the pre-test scores of the summative assessment are taken as the covariate, and the post-test scores of the summative assessment are taken as the dependent variable. Before ANCOVA, the homogeneity of variance assumption was tested. The Levene's test for 
equality of variances was not significant $(\mathrm{F}=1.314, \mathrm{p}>0.05)$. In addition, the assumption of homogeneity of regression coefficients was also tested $(\mathrm{F}=1.349, \mathrm{p}>0.05)$. The results indicate that neither homogeneity assumption was violated. The results of the ANCOVA analysis are shown in Table 2 .

\begin{tabular}{lrrrrr}
\hline Sources & \multicolumn{1}{c}{ SS } & df & MS & F & Post Hoc \\
\hline Pre-test & 3212.755 & 1 & 3212.755 & $11.684^{* *}$ & \\
TTM & 5986.231 & 1 & 5986.231 & $21.771^{* *}$ & IWB > T \\
Error & 14023.393 & 51 & 274.968 & & \\
Total & 191440.000 & 54 & & & \\
Corrected Total & 26104.000 & 53 & & & \\
\hline
\end{tabular}

** $\mathrm{p}<.01$

TTM: Two different types of teaching method

IWB: Interactive Whiteboard group

T: Traditional ICT-integrated group

Table 2. ANCOVA summary table $(n=54)$

Table 2 shows that the pre-test scores have a significant influence on the post-test scores $(\mathrm{F}=11.684, \mathrm{p}<0.01)$. Further, the TTM also has a significant influence on the scores of posttest $(\mathrm{F}=21.771, \mathrm{p}<0.01)$. The result means that student learning in instructional environments using the two different types of teaching method has significantly different learning effectiveness. Moreover, after conducting the LSD PostHoc analysis, it is found that students in the IWB group have significantly better learning effectiveness than those in the T group.

\subsection{Effect size analysis on the effectiveness of two different types of teaching method in facilitating student learning}

This study uses the effect size to investigate the effectiveness of the two different types of teaching method in facilitating student learning. In Table 3, the results show that the effect size of student learning effectiveness in the IWB group is 2.214, while the effect size of student learning effectiveness in the T group is 0.888. Based on the above, it is known that students in the IWB group have better learning effectiveness than students in the T group. This study further investigates the effectiveness of the two different types of teaching method in facilitating students to learn the three different sub-topics. In Table 3, the results show that students in the IWB group have better learning effectiveness than those in the T group across all three sub-topics. The effect sizes of IWB group student effectiveness in learning the three sub-topics all belong to 'large' effect size (Chromosome and Its Significance: Cohen's $d=1.646$; The Role of Mitosis: Cohen's $d=1.041$; Meiosis and Sexual Life Cycle: Cohen's $d=0.957)$. However, in the T group, the effect size of student effectiveness in learning the sub-topic of 'Chromosome and Its Significance' belongs to 'large' effect size (Cohen's $d=1.278$ ). The effect size of student effectiveness in learning the sub-topics of 'The Role of Mitosis' (Cohen's $d=0.627$ ) and 'Meiosis and Sexual Life Cycle' (Cohen's $d=0.269$ ) belong to ' middle to large' effect size and 'small to middle' effect size. These results show 
that integrating an IWB into teaching can lead to better learning effectiveness for the cell division topic. Moreover, compared with the T group, student learning effectiveness for the two sub-topics, 'The Role of Mitosis' and 'Meiosis and Sexual Life Cycle,' is especially effective in the IWB group.

\begin{tabular}{|c|c|c|c|c|c|c|}
\hline \multirow{2}{*}{$\begin{array}{l}\text { Teaching } \\
\text { sub-topics }\end{array}$} & \multicolumn{3}{|c|}{ IWB group $(n=27)$} & \multicolumn{3}{|c|}{$T$ group $(n=27)$} \\
\hline & $\begin{array}{l}\text { Pre-test } \\
(\%)\end{array}$ & $\begin{array}{c}\text { Post-test } \\
(\%)\end{array}$ & Cohen's $d$ & $\begin{array}{l}\text { Pre-test } \\
(\%)\end{array}$ & $\begin{array}{c}\text { Post-test } \\
(\%)\end{array}$ & Cohen's $d$ \\
\hline $\begin{array}{l}\text { Chromosome } \\
\text { and Its } \\
\text { Importance } \\
(\mathrm{n}=7)\end{array}$ & $\begin{array}{c}31.6 \\
(\mathrm{SD}=19.2)\end{array}$ & $\begin{array}{c}63.4 \\
(\mathrm{SD}=19.5)\end{array}$ & 1.646 & $\begin{array}{c}27.5 \\
(\mathrm{SD}=15.0)\end{array}$ & $\begin{array}{c}54.5 \\
(\mathrm{SD}=25.8)\end{array}$ & 1.278 \\
\hline $\begin{array}{l}\text { The Role of } \\
\text { Mitosis }(n=7)\end{array}$ & $\begin{array}{c}26.0 \\
(\mathrm{SD}=22.1)\end{array}$ & $\begin{array}{c}52.0 \\
(\mathrm{SD}=27.6)\end{array}$ & 1.041 & $\begin{array}{c}25.4 \\
(\mathrm{SD}=15.2)\end{array}$ & $\begin{array}{c}39.6 \\
(\mathrm{SD}=28.3)\end{array}$ & 0.627 \\
\hline $\begin{array}{l}\text { Meiosis and } \\
\text { Sexual Life } \\
\text { Cycle }(n=11)\end{array}$ & $\begin{array}{c}35.6 \\
(\mathrm{SD}=17.3)\end{array}$ & $\begin{array}{c}50.5 \\
(\mathrm{SD}=13.7)\end{array}$ & 0.957 & $\begin{array}{c}32.3 \\
(\mathrm{SD}=13.2)\end{array}$ & $\begin{array}{c}36.7 \\
(\mathrm{SD}=18.9)\end{array}$ & 0.269 \\
\hline Total & $\begin{array}{c}35.2 \\
(\mathrm{SD}=14.7)\end{array}$ & $\begin{array}{c}68.1 \\
(\mathrm{SD}=16.2)\end{array}$ & 2.214 & $\begin{array}{c}29.0 \\
(\mathrm{SD}=9.2)\end{array}$ & $\begin{array}{c}42.5 \\
(\mathrm{SD}=19.4)\end{array}$ & 0.888 \\
\hline
\end{tabular}

Pre-test: The average correct answering rate of items about three different learning topics in the pre-test of the summative assessment.

Post-test: The average correct answering rate of items about three different learning topics in the posttest of the summative assessment.

Table 3. Effect size analysis on students' learning effectiveness about three different subtopics

\section{Concluding remarks}

Cell division has always been one of the topics both students and teachers find difficult for students to learn, and meiosis is the most difficult part (Brown, 1995; Oztap et al., 2003). Brown (1995) and Oztap et al. (2003) argued that the teaching method is one of the reasons student have difficulty in learning cell division. Brown suggested that to help students learn, the dynamic nature of cell division should be emphasized and teachers should properly use $2 \mathrm{D}$ and $3 \mathrm{D}$ pictures to help students build chromosome models. The findings of this study show that compared to traditional ICT-integrated instruction, IWB is more effective in improving student learning in cell division. Among all sub-topics of cell division, IWB is especially effective in assisting students in learning 'The Role of Mitosis' 
and 'Meiosis and Sexual Life Cycle.' Traditional ICT-integrated instruction can only improve student learning effectiveness for the sub-topic of 'Chromosome and Its Significance'. This may be because compared with the traditional ICT-integrated instruction, IWB can better consolidate multimodal representations, combining the key concepts, such as genes, chromosomes, and genetic information, more closely together with the terminology and more clearly presenting their relationships. Students can therefore develop a more coherent conceptual framework to serve as basis of their learning of cell division. This may resolve the learning difficulties caused by the basic concepts - cell, nucleus, gene and genetic information and the relationships between them which are implied separately in different teaching topics (Lewis et al., 2000b).

The interactive nature of IWB improves interaction between the teacher and students and peers. In teaching of the two sub-topics, 'The Role of Mitosis' and 'Meiosis and Sexual Life Cycle,' this study tries to make the interactive nature of IWB more closely integrated into teaching activities. Students work together to complete the tasks of answering questions about the processes of the two kinds of cell division and thinking about the difference between mitosis and meiosis by comparison of the chromosome duplication, number of divisions, number of daughter cells and genetic composition. This may explain why students have better learning effectiveness. According to several researchers (Levy, 2002; Torff \& Tirotta, 2010; Wall, Higgins, \& Smith, 2005), students think that when they are allowed to use IWB, their learning can be greatly improved and their learning process can be better facilitated. In traditional ICT-integrated instruction, the interaction between the teacher and students is limited to verbal communication and the messages are delivered by PPT slides in a more linear way. By comparison, an IWB can better integrate multimedia presentations. This may be the reason that students have lower learning effectiveness when traditional ICT-integrated instruction is adopted.

\section{Educational implications}

Based on research findings, this study argues that the teaching methods are the reason cell division is thought to be the topic most difficult to learn by junior high school students, following Brown (1995) and Lewis et al. (2000b). Oztap et al.( 2003) showed that students do not have a coherent conceptual framework and often feel confused about genetic terminology. If the relationship between basic structures such as cell, nucleus, chromosomes and genes can be clearly presented and students can be assisted in building chromosome models, they will be able to overcome learning difficulties. Brown (1995) also stated that during teaching activities, both 2D pictures and 3D pictures were suggested to be provided to help students build chromosome models. According to Brown, this study suggests that during teaching activities, teachers can try to integrate multimedia into the teaching of the 'Chromosome and Its Significance.' For example, pictures of a dyed cell under microscope can be used to demonstrate the relationship between cell, nucleus and chromosomes, 2D and $3 \mathrm{D}$ pictures can be used to show the structure of chromosome, and dynamic videos or animations can be used to present the chromatin packing in a eukaryotic chromosome. After students have a clear understanding of basic genetic concepts and develop a more coherent conceptual framework, they will find it easier to learn more about cell division.

Currently, the traditional ICT-integrated instruction always uses Microsoft PowerPoint slides (PPT slides) to enrich classroom teaching. Although PPT slides allow teachers to 
integrate multimedia presentation, the slides do not support Adobe-Flash-animation-based interactive media. They can only be presented in a linear and page-by-page way when used in teaching activities, which makes the teaching possibilities more restricted. However, this study integrates an IWB into teaching. IWB can integrate both multimedia and Adobe-Flashanimation-based interactive media presentation to help teachers perform multimedia and multimodal teaching. Moreover, IWB supports rapid cross-page comparison and zoned page presentation. The differences between the two kinds of cell division can be clearly shown, enabling better understanding. The key characteristic of IWB, high interactivity, allows teachers to have more eye-contact and interaction with students, in addition to verbal communication. It is also easier for teachers to design activities facilitating interaction and cooperation between students. Teachers and students feel closer to each other, as Wood (2002) argued, and students are more motivated to concentrate on and participate in teaching activities (Homles, 2009; Northcote et al., 2010; Slay et al., 2008; Smith et al., 2005; Wall et al., 2005). These advantages largely overcome the limitations of PPT slides in teaching and student learning effectiveness. Based on the findings of this study, building chromosome models is vital to the learning of cell division. The dynamic process of cell division and the micro-view of chromosome changes are also keys to overcome student learning difficulties in understanding cell division. If ICT and multimedia and multimodal presentation can be properly used, student learning will be more effective when studying cell division.

\section{Note}

- It is herein stated that all the trademarks and product names referred to in this research are the property of their respective owners. In addition, all the figures adopted in this research are the property of their respective owners.

- Some objects used in the Figure 2, Figure 3, Figure 4, and Figure 5 are adopted from the NoteBook ${ }^{\mathrm{TM}}$ software. The Figure 3, Figure 4, Figure 5 and Figure 6 are screenshots of the e-Learning materials in this research. The e-Learning materials are constructed by the NoteBook ${ }^{\mathrm{TM}}$ software. For more information about the NoteBook ${ }^{\mathrm{TM}}$ software, you can visit http://smarttech.com/

\section{Acknowledgement}

The authors deeply appreciate the National Science Council in Taiwan for the financial support and encouragement under Grant No. 97-2511-S-134-006-MY2 and 99-2511-S-134002-MY3.

\section{References}

British Educational Communications and Technology (BECTA) (2007). Harnessing Technology schools survey 2007. In: BECTA, 23.07.2011, Available from http://dera.ioe.ac.uk/1554/1/becta_2007_htssfindings_report.pdf

Brown, C. R. (1995).The effective teaching of biology. Longman publishing, ISBN 0582095050, New York, USA.

Cohen, J. (1988). Statistical power analysis for the behavioral sciences, Erlbaum, ISBN 0805802835, Hillsdale, NJ. 
Glover, D., Miller, D., Averis, D., \& Door, V. (2005). The interactive whiteboard: a literature survey, Technology, Pedagogy and Education, Vol.14, No.2, pp.155-170, ISSN 1475939X.

Holmes, K. (2009). Planning to teach with digital tools: Introducing the interactive whiteboard to pre-service secondary mathematics teachers, Australasian Journal of Educational Technology, Vol.25, No.3, pp.351-365, ISSN 1449-3098.

Levy, P. (2002). Interactive whiteboards in learning and teaching in two Sheffield schools: A developmental study. In: The University of Sheffield. 23.07.2011, Available from http://dis.shef.ac.uk/eirg/projects/wboards.htm

Lewis, J., \& Wood-Roinson, C. (2000). Genes, chromosomes, cell devision and inheritance do students see any relationship? International Journal of Science Education, Vol.22, No.2, pp.177-197, ISSN 0950-0693.

Lewis, J, Leach, J, \& Wood-Roinson, C. (2000a). What's in a cell? - young people's understanding of the genetic relationship between cells, within an individual, International Journal of Biological Education, Vol.34, No.3, pp.129-132, ISSN 00219266.

Lewis, J, Leach, J, \& Wood-Roinson, C. (2000b). Chromosomes: The missing link - young people's understanding of mitosis, meiosis, and fertilization, International Journal of Biological Education, Vol.34, No.4, pp.189-199, ISSN 0021-9266.

Northcote, M., Mildenhall, P., Marshall, L., \& Swan, P. (2010). Interactive whiteboards: Interactive or just whiteboards? Australasian Journal of Educational Technology, Vol. 26, No.4, pp.494-510, ISSN 1449-3098.

Oztap, H., Ozay, E., \& Oztap, F. (2003). Teaching cell division to secondary school students: An investigation of difficulties experienced by Turkish teachers, International Journal of Biological Education, Vol. 38, No.1, pp.13-15, ISSN 0021-9266.

Slay, H., Sieborger, I., \& Hodgkinson-Williams, C. (2008). Interactive whiteboard: Real beauty or just lipstick? Computers $\mathcal{E}$ Education, Vol. 51, No. 3, pp. 1321-1341, ISSN 0360-1315.

Smith, H. J., Higgins, S., Wall, K., \& Miller, J. (2005). Interactive whiteboards: boon or bandwagon? A critical review of the literature, Journal of Computer Assisted Learning, Vol.21, No.2, pp.91- 101, ISSN 0266-4909.

Smith, M. U. (1991). Teaching cell division: Students' difficulties and teaching recommendations, Journal of College Science Teaching, Vol. 21, No. 1, pp.28-33, ISSN 0047-231X.

Torff, B. \& Tirotta, R. (2010). Interactive whiteboards produce small gains in elementary students' self-reported motivation in mathematics, Computers $\mathcal{E}$ Education, Vol.54, No.2, pp.379-383, ISSN 0360-1315.

Wall, K., Higgins, S., \& Smith, H. J. (2005). “The visual helps me understand the complicated things": Pupil views of teaching and learning with interactive whiteboards, British Journal of Education Technology, Vol.36, No.5, pp. 851-867, ISSN 0007-1013.

Wood, C. (2002). Interactive whiteboards - a luxury too far? In: The Association for ICT in Education, 07.23.2011, Available from http://acitt.digitalbrain.com/acitt/web/resources/pubs/Journal\%2002/whiteboa rds.htm 
Yang, K. T., Wang, T. H., \& Chiu, M. H. (2011). Implementation of Interactive Whiteboard in improving the learning effectiveness of junior high school students with different cognitive styles - A case study of 'Cell Division'course, Curriculum $\mathcal{E}$ Instruction Quarterly, Vol.14, No.4, pp. 187-208, ISSN 1560-1277. 


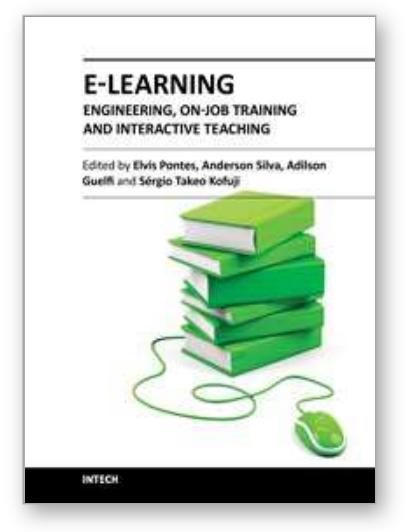

\author{
E-Learning - Engineering, On-Job Training and Interactive \\ Teaching \\ Edited by Dr. Sergio Kofuji
}

ISBN 978-953-51-0283-0

Hard cover, 238 pages

Publisher InTech

Published online 14, March, 2012

Published in print edition March, 2012

Adaptive E-learning was proposed to be suitable for students with unique profiles, particular interests, and from different domains of knowledge, so profiles may consider specific goals of the students, as well as different preferences, knowledge level, learning style, rendering psychological profile, and more. Another approach to be taken into account today is the self-directed learning. Unlike the adaptive E-learning, the Selfdirected learning is related to independence or autonomy in learning; it is a logical link for readiness for Elearning, where students pace their classes according to their own needs. This book provides information on the On-Job Training and Interactive Teaching for E-learning and is divided into four sections. The first section covers motivations to be considered for E-learning while the second section presents challenges concerning Elearning in areas like Engineering, Medical education and Biological Studies. New approaches to E-learning are introduced in the third section, and the last section describes the implementation of E-learning Environments.

\title{
How to reference
}

In order to correctly reference this scholarly work, feel free to copy and paste the following:

Kai-Ti Yang and Tzu-Hua Wang (2012). Interactive WhiteBoard: Effective Interactive Teaching Strategy Designs for Biology Teaching, E-Learning - Engineering, On-Job Training and Interactive Teaching, Dr. Sergio Kofuji (Ed.), ISBN: 978-953-51-0283-0, InTech, Available from: http://www.intechopen.com/books/e-learningengineering-on-job-training-and-interactive-teaching/interactive-whiteboard-effective-interactive-teachingstrategy-designs-for-biology-teaching

\section{INTECH}

open science | open minds

\section{InTech Europe}

University Campus STeP Ri

Slavka Krautzeka 83/A

51000 Rijeka, Croatia

Phone: +385 (51) 770447

Fax: +385 (51) 686166

www.intechopen.com

\section{InTech China}

Unit 405, Office Block, Hotel Equatorial Shanghai

No.65, Yan An Road (West), Shanghai, 200040, China 中国上海市延安西路65号上海国际贵都大饭店办公楼 405 单元

Phone: +86-21-62489820

Fax: +86-21-62489821 
(C) 2012 The Author(s). Licensee IntechOpen. This is an open access article distributed under the terms of the Creative Commons Attribution 3.0 License, which permits unrestricted use, distribution, and reproduction in any medium, provided the original work is properly cited. 